\title{
Studi perilaku dating violence pada mahasiswa di kabupaten Pringsewu
}

\author{
Florentius Yogie Pratama ${ }^{*}$, Hasni Diana ${ }^{2}$ \\ 1,2Universitas Aisyah Pringsewu Lampung \\ Jl. A. Yani 1A Tambahrejo Kecamatan Gadingrejo Kabupaten Pringsewu Lampung 35372 \\ e-mail: ${ }^{* 1}$ fypratama1@gmail.com, 2 hasnidiana@aisyah.ac.id,
}

\begin{abstract}
This study belongs to a descriptive study that aims at obtaining the description about violence in dating among adolescents' overview as students at Kabupaten Pringsewu. The type of this research is a descriptive study using survey method. The research instrument used is a questionnaire about types of dating violence among student consisting of 58 items. The subject is the college student consisting of 184 people. The technique of data analysis is using categorized descriptive technique that begins with a score tabulation of each item, then categorizing the types of dating violence encountered by students. This categorization consists of three levels, they are high, medium, and low. The results show that: (1) The types of dating violence encountered by college students indicate that 58 items belong to the rare category, 2 items belong to the frequent category, and no items belong to the often category. (2) Based on the analysis of the items in the questionnaire that belong to high frequency, the writer suggested the implied guidance topics in compiling the healthy and safe dating guidance program.
\end{abstract}

Keywords: Dating violence; student; dating; violence

\begin{abstract}
Abstrak. Penelitian ini merupakan penelitian deskriptif yang bertujuan untuk memperoleh gambaran mengenai bentuk kekerasan dalam berpacaran pada mahasiswa di Kabupaten Pringsewu. Jenis penelitian adalah penelitian deskriptif dengan metode survei. Instrumen penelitian yang dipakai adalah kuesioner Bentuk-bentuk Kekerasan dalam Pacaran dengan jumlah 58 item. Subyek penelitian adalah mahasiswa sebanyak 184 orang. Teknik analisis data dalam penelitian ini menggunakan teknik deskriptif kategoris yang diawali dengan tabulasi skor tabulasi skor dari masing- masing item, selanjutnya mengkategorisasikan bentuk-bentuk kekerasan dalam pacaran yang dialami. Kategorisasi ini terdiri dari tiga jenjang yaitu tinggi, sedang, dan rendah. Hasil penelitian memperlihatkan bahwa (1) Bentuk-bentuk kekerasan dalam berpacaran pada mahasiswa di Kabupaten Pringsewu termasuk dalam kategori "jarang" terdapat 58 butir item, dan terdapat kategori kerap kali 2 item, dan bentuk kekerasan dalam pacaran yang terjadi kategori sering tidak ada. (2) Berdasarkan analisis butir-butir kuesioner bentuk-bentuk kekerasan dalam pacaran, yang terindikasi 10 frekuensi tinggi, diusulkan topik bimbingan yang implikatif dalam bimbingan pacaran yang sehat dan aman.
\end{abstract}

Kata kunci: Dating violence; mahasiswa; pacaran; kekerasan

\section{Pendahuluan}

Masa remaja merupakan masa peralihan dari anak-anak menuju dewasa yang mencakup kematangan mental, emosional, sosial dan fisik. Banyak hal yang terjadi di masa remaja, salah satu yang menarik adalah trend berpacaran. Fenomena berpacaran sudah sangat umum terjadi di kalangan remaja. Pacaran merupakan suatu proses dua manusia lawan jenis untuk saling mengenal dan memahami, dan 
belajar membina hubungan sebagai persiapan pranikah, untuk menghindari terjadinya ketidakcocokan dan permasalahan pada saat setelah menikah. Masing- masing berusaha mengenal kebiasaan, karakter atau sifat, dan reaksi-reaksi terhadap berbagai masalah maupun peristiwa.

Pacaran merupakan proses perkenalan antara dua insan manusia (Hadi:2010). Pacaran berarti tahap untuk saling mengenal antara seorang laki-laki dan perempuan yang saling tertarik dan berminat untuk menjalin hubungan yang eksklusif (terpisah, sendiri, istimewa). Pacaran memang diarahkan untuk suatu hubungan yang lebih lanjut, lebih dalam, dan lebih pribadi. Ini tidak boleh diartikan sebagai keharusan untuk melanjutkan. Pacaran dimaksudkan sebagai situasi yang memungkinkan pasangan yang berelasi semakin dekat dan akhirnya menemukan kecocokan satu sama lain untuk melanjutkan hidup bersama dalam ikatan resmi, berbentuk perkawinan.

Indahnya romantika pacaran seringkali menghipnotis remaja sehingga lupa bahwa di balik indahnya pacaran, justru membawa dirinya ke dalam situasi yang tidak menyenangkan, bahkan akan menjadi cerita yang tidak akan terlupakan seumur hidup. Dalam aktifitas pacaran, ada kalanya bisa terjadi hal-hal yang menimbulkan kekerasan. Sebagian besar remaja beranggapan bahwa dalam berpacaran tidak mungkin terjadi kekerasan, karena masa berpacaran merupakan masa yang penuh dengan hal - hal yang indah, yang setiap hari diwarnai oleh manisnya tingkah laku dan kata - kata yang dilakukan dan diucapkan oleh dua sejoli yang sedang dimabuk asmara. Orang sering tidak sadar bahwa sebuah hubungan pacaran dapat berubah menjadi tidak sehat dan dapat memunculkan kekerasan.

Kekerasan adalah suatu tindakan berdasarkan perbedaan jenis kelamin yang mengakibatkan kesengsaraan atau penderitaan secara fisik, seksual atau psikologis, termasuk ancaman tindakan tertentu, pemaksaan atau perampasan kemerdekaan secara sewenang-wenang, baik yang terjadi di depan umum atau dalam kehidupan pribadi (Arya, 2010). Kekerasan yang terjadi ini biasanya terdiri dari beberapa jenis, misalnya: serangan terhadap fisik, mental/psikis, ekonomi dan seksual. Dari segi fisik, kekerasan yang dilakukan bisa berupa: memukul, meninju, menendang, menjambak, mencubit, dan lain sebagainya. Dari segi mental, bentuk kekersan biasanya seperti: cemburu yang berlebihan, pemaksaan, memaki- maki di depan umum, dan lain sebagainya. Kekerasan dalam hal ekonomi, misalnya: jika pasangan sering meminjam uang atau barang-barang lain tanpa pernah mengembalikannya, selalu minta ditraktir, dan lain-lain. Kekerasan dalam hal seksual bisa berbentuk, misalnya dipaksa dicium oleh pacar, kemudian mulai meraba-raba tubuh atau memaksa untuk melakukan hubungan seksual.

Kekerasan dalam berpacaran telah banyak terjadi di Indonesia, seperti yang dilansir dalam LBH APIK (Lembaga Bantuan Hukum Asosiasi Perempuan Indonesia untuk Keadilan) bahwa selama tahun 2009, LBH APIK menerima pengaduan dan pendampingan sebanyak 56 kasus kekerasan dalam pacaran. Tahun 2001 Rumah Sakit Bhayangkara di Makasar membuka pelayanan satu atap (one stop service) dalam menangani masalah kekerasan terhadap perempuan. Selama 1 tahun ada 7 kasus kekerasan dalam pacaran yang dilaporkan. PKBI Yogyakarta mendapatkan bahwa dari bulan Januari hingga Juni 2001 saja, terdapat 47 kasus kekerasan dalam berpacaran, 57\% diantaranya adalah kekerasan emosional, 20\% mengaku mengalami kekerasan seksual, 15\% mengalami kekerasan fisik, dan 8\% lainnya merupakan kasus kekerasan ekonomi. Januari hingga Juni 2011 PKBI Yogyakarta juga menemukan 27 kasus kekerasan dalam pacaran yang 15\% di antaranya kekerasan fisik, 57\% kekerasan emosional, 8\% kekerasan seksual, dan 20\% kekerasan ekonomi. (Kesrepro.info)

Harian Tribun Jogja (17 Juli 2012) memberitakan bahwa 14 perempuan meninggal akibat kekerasan saat menjalani pacaran. Data yang telah disampaikan di atas menunjukkan bahwa tindak kekerasan yang terjadi saat berpacaran di Indonesia berada dalam tingkat yang mengkhawatirkan. Hal ini berkaitan dengan dampak yang diterima oleh sang korban karena kekerasan dalam berpacaran. Para korban umumnya bersikap pasif, mereka hanya diam, tidak berani melapor atau bercerita kepada orang 
lain karena beberapa alasan, diantaranya: malu, terlalu sayang kepada pacar, takut ditinggalkan, beranggapan masalah tersebut merupakan hal yang terlalu pribadi, tidak tahu harus berbuat apa, dan ketakutan akan ancaman dan kenekatan sang pacar.

Sedikit sekali masyarakat yang tahu adanya kekerasan yang terjadi dalam pacaran, karena sebagian besar menganggap bahwa masa pacaran adalah masa yang penuh dengan hal-hal yang indah. Kekerasan dalam berpacaran merupakan masalah yang masih belum banyak terungkap karena ketidaktahuan masyarakat, akibat kurangnya informasi dan data dari laporan korban mengenai kekerasan tersebut. Permasalahan kekerasan dalam berpacaran harus segera dicari solusinya, karena remaja adalah penerus bangsa yang akan memegang peranan penting bagi kemajuan bangsa. Apabila dalam masa remaja sesorang mendapat perlakuan yang kasar, maka pengalaman tersebut akan berdampak pada kejiwaan. Karena remaja merupakan harapan bangsa, maka tentunya kita tidak menginginkan bila remaja kita lemah dan rapuh dalam mental, psikis, dan spiritualnya.

Fenomena di atas, menunjukkan tindak kekerasan yang terjadi saat berpacaran cukup mengkhawatirkan dan sangat merugikan, maka dari itu diperlukan peran dari guru Bimbingan dan Konseling sebagai sarana perubahan untuk membantu dengan memberikan informasi sesuai dengan apa yang dibutuhkan siswa sebagai subjek bimbingan. Di samping itu, peran guru bimbingan adalah membimbing dan mengarahkan siswa untuk dapat mengambil keputusan yang tepat untuk tercapainya tujuan yang telah ditetapkan. Layanan bimbingan dan konseling merupakan upaya pemberian bantuan yang dirancang dengan memfokuskan pada kebutuhan, kekuatan, minat, dan isu-isu yang berkaitan dengan tahapan perkembangan anak dan merupakan bagian penting dan integral dari keseluruhan program pendidikan.

Bimbingan merupakan bantuan dalam memberikan informasi dengan menyajikan pengetahuan yang dapat digunakan untuk mengambil suatu keputusan. Tujuan bimbingan adalah membimbing dan mengarahkan seseorang atau individu ke suatu tujuan dan mengatur kehidupan sendiri, menjamin perkembangan dirinya seoptimal mungkin, memikul tanggung jawab atas arah hidupnya dan menyelesaikan tugas yang dihadapi dalam kehidupan secara memuaskan. Untuk memperoleh pemahaman mengenai pacaran yang sehat dan aman, remaja memerlukan bimbingan. Bimbingan merupakan salah satu cara untuk mencegah kekerasan di dalam berpacaran bagi remaja. Berdasarkan pada uraian di atas, maka penulis tertarik untuk mengadakan penelitian dengan judul Studi Perilaku Dating Violence pada Mahasiswa di Kabupaten Pringsewu.

\section{Metode}

Penelitian ini tergolong penelitian deskriptif. Furchan (2007: 447) mengatakan penelitian deskriptif merupakan penelitian yang dirancang untuk memperoleh informasi tentang status gejala pada saat penelitian dilakukan, menjelaskan data apa adanya dalam situasi sekarang.

\section{Partisipan penelitian}

Partisipan dalam penelitian adalah Mahasiswa di Kabupaten Pringsewu Sejumlah 155 orang yang sedang menjalani kuliah di Universitas Aisyah Pringsewu dari semester satu hingga semester enam. Penelitian ini dilaksanakan dalam kurun waktu bulan April - Juni 2019. 


\section{Prosedur penelitian}

Penelitian ini diawali dengan melakukan penyusunan kuesioner oleh peneliti, mengidentifikasi aspek-aspek kekerasan dalam pacaran yang akan diungkap, mengidentifikasi indikator-indikator dari aspek kekerasan dalam pacaran. Langkah selanjutnya adalah merumuskan item-item yang mengungkap berbagai aspek yang hendak diteliti berdasarkan indikator kekerasan dalam pacaran. Peneliti kemudian melakukan uji coba empirik kuesioner kekerasan dalam pacaran bertujuan untuk mengetahui tingkat validitas dan reliabilitas instrumen/alat ukur, sehingga didapatkan kelayakan penggunaannya sebagai alat ukur yang dapat dihandalkan dan benar-benar mengungkap apa yang diteliti. Tahap pelaksanaan pengambilan data dilaksanakan pada hari Senin dan Kamis dalam kurun waktu bulan April-Juni 2019 di Universitas Aisyah Pringsewu (UAP) dengan responden sebanyak 155 Mahasiswa.

\section{Instrumen}

Alat yang digunakan dalam penelitian ini berbentuk kuesioner yang disusun dalam bentuk rating scale (skala bertingkat) yang mengikuti rinsip-prinsip skala Likert, yaitu suatu ukuran subjektif yang memuat sejumlah pernyataan. Masing-masing pernyataan dilengkapi dengan pilihan jawaban yang menunjukkan jarang, kerap kali, sering. Masing-masing tingkatan diberi nilai angka yang sesuai dengan tingkatan sikap responden. Metode yang digunakan dalam skala penelitian ini adalah metode skoring yang dijumlahkan (Method of Summated Rating). Kuesioner kekerasan dalam pacaran ini akan terdiri dari dua bagian yaitu (1) bagian pengantar, identitas responden serta petunjuk pengisian dan (2) bagian pernyataan yang mengungkap bentuk-bentuk kekerasan dalam pacaran mahasiswa di Kabupaten Pringsewu Lampung. Kuesioner dikonstruk berdasarkan aspek bentuk kekerasan dalam pacaran yaitu kekerasan secara verbal dan emosional, seksual, fisik. Kuesioner dinyatakan dalam satu bentuk pernyataan yaitu tentang bentuk-bentuk kekerasan dalam pacaran.

\section{Analisis data}

Analisis data dalam penelitian ini adalah dengan cara mengkategorisasikan frekuensi bentukbentuk kekerasan dalam pacaran menurut Azwar (2008 : 107-108) dengan tiga katagori; sering, kerap kali, jarang. 


\section{Hasil Penelitian}

Tabel 1.

Gambaran Umum Partisipan Berdasarkan Jenis Kelamin, Usia, Frekuensi Berganti Pacar, dan Agama.

\begin{tabular}{|c|c|c|c|c|c|c|}
\hline \multirow{2}{*}{ Kategori } & \multicolumn{4}{|c|}{ Jenis kelamin } & \multirow{2}{*}{ Total (\%) } & \multirow{2}{*}{ Jumlah } \\
\hline & Laki- laki & Prosentase & Perempuan & Prosentase & & \\
\hline \multicolumn{7}{|l|}{ USIA } \\
\hline 20 Tahun & 2 & 1,03 & 5 & 3,02 & 4,52 & 7 \\
\hline 19 Tahun & 21 & 13,55 & 27 & 17,42 & 30,97 & 48 \\
\hline 18 Tahun & 32 & 20,65 & 63 & 40,65 & 61,29 & 95 \\
\hline 17 Tahun & 1 & 0,65 & 4 & 2,58 & 3,23 & 5 \\
\hline Total (\%) & & 36,12 & & 63,88 & 100 & \\
\hline Jumlah & 56 & & 99 & & & 155 \\
\hline \multicolumn{7}{|l|}{ BERGANTI PACAR } \\
\hline 1 Kali & 10 & 6,45 & 6 & 3,87 & 10,32 & 16 \\
\hline 2 Kali & 6 & 3,87 & 10 & 6,45 & 10,32 & 16 \\
\hline 3 Kali & 6 & 3,87 & 21 & 13,55 & 17,42 & 27 \\
\hline 4 Kali & 8 & 5,16 & 11 & 7,10 & 12,26 & 19 \\
\hline 5 Kali & 13 & 8,39 & 23 & 14,84 & 23,23 & 36 \\
\hline Lebih Dari 5 Kali & 13 & 8,39 & 28 & 18,06 & 26,45 & 41 \\
\hline Total $(\%)$ & & 36,13 & & 63,87 & 100 & \\
\hline Jumlah & 56 & & 99 & & & 155 \\
\hline \multicolumn{7}{|l|}{ AGAMA } \\
\hline Islam & 52 & 35,48 & 82 & 52,90 & 86,45 & 134 \\
\hline Khatolik & 2 & 1,3 & 8 & 5,16 & 6,45 & 10 \\
\hline Kristen & 2 & 1,3 & 9 & 5,8 & 7,10 & 11 \\
\hline Hindhu & 0 & & 0 & & & \\
\hline Budha & 0 & & 0 & & & \\
\hline TOTAL (\%) & & 36,13 & & 63,87 & 100 & \\
\hline Jumlah & 56 & & 99 & & & 155 \\
\hline
\end{tabular}

Berdasarkan tabel 1 dapat diketahui bahwa sebanyak 155 partisipan terlibat dalam penelitian dating violence. Berdasarkan jenis kelamin partisipan dalam katagori umur, proposi remaja perempuan lebih besar, yaitu sebesar 63,88\% apabila dibandingkan dengan remaja laki-laki, yaitu sebanyak 36,12\%.

Katagori berganti pacar, remaja putri lebih besar dari pada remaja putra yakni 63,87 berbanding 36,13 . Kategori agama remaja putra lebih kecil dibanding remaja putri, dengan berbagai perbedaan agama.

Penelitian ini bertujuan untuk mengetahui bentuk-bentuk kekerasan dalam pacaran pada mahasiswa di Kabupaten Pringsewu. Penelitian ini, ada tiga kategori bentuk kekerasan dalam pacaran yang dialami para siswa berdasarkan nilai rata-rata total, yaitu kategori jarang, kategori kerap sekali, dan kategori sering diperoleh gambaran sebagaimana disajikan pada tabel 2: 
Tabel 2. Pengolongan Bentuk-bentuk Dating Violence dalam tiga kategori

\begin{tabular}{|c|c|c|c|}
\hline Katagori & Indikator & No Pernyataan & Jumlah \\
\hline \multirow[t]{17}{*}{ Frekuensi Jarang } & Name calling & $1,2,3,4$ & 4 \\
\hline & Intimidating looks & 6,7 & 2 \\
\hline & Use of pagers and cell phones & $8,10,11,12,13,14,15$ & 8 \\
\hline & Making a boy/girl wait by the phone & 16,17 & 2 \\
\hline & Monopolizing a girl's/boy's time & 18,19 & 2 \\
\hline & Making a girl's/ boy`s feel insecure & $20,21,22$ & 3 \\
\hline & Blaming & 23,24 & 2 \\
\hline & Making threats & $25,26,27,28$ & 4 \\
\hline & Manipulation / making himself look pathetic & 29,30 & 2 \\
\hline & Interrogating & $31,32,33,34,35$ & 5 \\
\hline & Humiliating her/him in public & $36,37,38,39,40$ & 5 \\
\hline & Breaking treasured items & $41,42,43$ & 3 \\
\hline & Perkosaan & 44, & 1 \\
\hline & Sentuhan yang tidak diinginkan & 45, & 1 \\
\hline & Memukul, mendorong, membenturkan & $46,47,48,49,50,51,52,53,54$ & 9 \\
\hline & Mengendalikan, menahan & $55,56,57$ & 3 \\
\hline & Permainan kasar & 58 & 1 \\
\hline Jumlah & & 56 & 56 item \\
\hline \multirow{2}{*}{ Frekuensi Kerap kali } & Intimidating looks & 5 & 1 \\
\hline & Use of pagers and cell phones & 9 & 1 \\
\hline Jumlah & & & 2 item \\
\hline \multicolumn{4}{|l|}{ Frekuensi Sering } \\
\hline Jumlah & & & 0 item \\
\hline
\end{tabular}

Berdasarkan tabel 2 didapatkan hasil perhitungan rata-rata skor total yang dapat disimpulkan bahwa banyak yang mengalami bentuk-bentuk kekerasan dalam kategori jarang, sesuai dengan tabel penggolongan subyek oleh Azwar (2009: 107-109).

Tabel 3. Lamanya hubungan pacaran berdasarkan jenis kelamin

\begin{tabular}{lcccccc}
\hline & \multirow{2}{*}{ Lama Berpacaran } & & \multicolumn{4}{c}{ Jenis Kelamin } \\
\cline { 3 - 7 } & & & Laki-laki & $\%$ & Perempuan & $\%$ \\
\hline < sebulan & 45 & 29,03 & 19 & 12,25 & 26 & 16,77 \\
\hline 1-6 bulan & 43 & 27,74 & 9 & 5,80 & 34 & 21,93 \\
\hline 6-1 tahun & 27 & 17,41 & 10 & 6,45 & 17 & 10,96 \\
\hline Lebih dari 1 tahun & 40 & 25,80 & 18 & 11,61 & 22 & 14,19 \\
\hline TOTAL & 155 & 100 & & 36,11 & & 63,09 \\
\hline
\end{tabular}

Remaja Laki-laki yang terlibat dalam dating violence mengalami masa berpacaran yang lebih kecil dibandingkan dengan remaja putri. Subjek partisipan laki-laki yang terlibat 36,11 \% dari $100 \%$ subyek, Untuk partisipan perempuan yang terlibat sebanyak 63,09\%. Subjek yang pernah berpacaran dan terlibat dalam dating violence memiliki masa berpacaran kurang dari 1 bulan 29,03\% dari seluruh subjek yang berpartisipasi. Subjek partisipan yang berpacaran 1-6 bulan sebanyak 27,74\% dan 17,41\% subjek partisipan berpacaran 6-1 tahun dan sisanya 25,80\% berpacaran lebih dari 1 tahun. 
Tabel 4. Analisis sepuluh butir bentuk-bentuk dating violence

\begin{tabular}{|c|c|c|c|c|}
\hline No & Butir & Rumusan & Skor & Peringkat \\
\hline 1. & 1 & $\begin{array}{l}\text { Menjelek-jelekkan tubuh saya (memberi julukan negatif, misalnya } \\
\text { “Gembrot, Cungkring) }\end{array}$ & 223 & 7 \\
\hline 2. & 3 & Mengatakan saya "malas" & 242 & 5 \\
\hline 3. & 5 & Mencemberuti saya dengan wajah kesal. & 271 & 2 \\
\hline 4. & 9 & Melarang saya melakukan sesuatu dengan lawan jenis & 287 & 1 \\
\hline 5. & 11 & Mengawasi pergaulan saya dengan orang lain. & 241 & 6 \\
\hline 6. & 14 & Membaca isi inbox saya dengan penuh curiga & 259 & 4 \\
\hline 7. & 33 & Mempertontonkan rasa cemburu yang berlebihan & 201 & 8 \\
\hline 8. & 34 & Menyatakan pada saya, seakan-akan saya sudah jadi miliknya. & 265 & 3 \\
\hline 9. & 8 & Melarang saya berbaur dengan lawan jenis & 191 & 9 \\
\hline 10. & 30 & Menyakiti saya dengan mengungkit-ungkit masa lalu & 184 & 10 \\
\hline
\end{tabular}

Tabel 5

Pengolongan Item Tertinggi Menurut Frekuensi

\begin{tabular}{|c|c|c|c|c|c|}
\hline \multirow{2}{*}{$\begin{array}{l}\text { No. } \\
\text { Item }\end{array}$} & \multirow{2}{*}{ Bentuk Kekerasan } & \multicolumn{4}{|c|}{ Frekuensi } \\
\hline & & $1-3 x$ & $4-6 X$ & $7-9 X$ & $>10 X$ \\
\hline 1 & $\begin{array}{l}\text { Menjelek-jelekkan tubuh saya (memberi julukan negatif, misal } \\
\text { “Gembrot, Cungkring) }\end{array}$ & 47 & 36 & 7 & 28 \\
\hline 3 & Mengatakan saya "malas" & 54 & 20 & 24 & 19 \\
\hline 5 & Mencemberuti saya dengan wajah kesal. & 56 & 26 & 15 & 29 \\
\hline 9 & Melarang saya melakukan sesuatu dengan lawan jenis. & 43 & 18 & 10 & 44 \\
\hline 11 & Mengawasi pergaulan saya dengan orang lain. & 60 & 18 & 11 & 28 \\
\hline 14 & Membaca isi inbox saya dengan penuh curiga & 51 & 18 & 13 & 32 \\
\hline 33 & Mempertontonkan rasa cemburu yang berlebihan & 62 & 12 & 13 & 19 \\
\hline 34 & Menyatakan pada saya, seakan-akan saya sudah jadi miliknya. & 60 & 28 & 11 & 29 \\
\hline 8 & Melarang saya berbaur dengan lawan jenis & 41 & 18 & 10 & 44 \\
\hline 30 & Menyakiti saya dengan mengungkit-ungkit masa lalu & 61 & 22 & 5 & 16 \\
\hline
\end{tabular}

Berdasarkan penelitian yang telah dilakukan dan hasil penelitian bentuk- bentuk kekerasan dalam pacaran pada mahasiswa menunjukkan bahwa Hampir semua siswa pernah mengalami bentuk-bentuk dating violence. Selain itu, hasil penelitian juga menunjukkan bahwa semua butir bentuk-bentuk dating violence termasuk dalam kategori jarang dan kerap kali serta terdapat 10 item yang mempunyai frekuensi yang tinggi.

Dating violence atau yang biasa disebut kekerasan dalam pacaran merupakan tindakan atau ancaman yang dilakukan secara sengaja baik melalui perilaku, perkataan maupun mimik wajah yang dilakukan salah satu pihak kepada pihak lain dalam hubungan pacaran. Perilaku ini ditujukan untuk memperoleh dan mempertahankan kekuatan atau kekuasaan dan kontrol atas pasangannya dalam hubungan pacaran. Banyak faktor yang mempengaruhi kekerasan dalam pacaran misalnya faktor individual, sejarah kekerasan dalam keluarga, alkohol bahkan karena jarang berhubungan dengan pihak yang lebih tua.

Hasil penelitian ini menunjukkan bahwa kekerasan dalam pacaran ada di kalangan siswa. Para siswa mengalami semua bentuk kekerasan dalam pacaran, yang meliputi empat jenis kekerasan, yaitu kekerasan verbal, kekerasan emosional, kekerasan seksual dan kekerasan fisik, di mana verbal dan emosional digabungkan. Riani (2012) Mengatakan bahwa kekerasan dalam pacaran kerap muncul dalam bentuk tindakan, yang meliputi kekerasan secara fisik, seksual, atau psikologis yang terjadi 
dalam sebuah hubungan pacaran, baik yang dilakukan di depan umum maupun dalam kehidupan pribadi.

Dari hasil itu terdapat beberapa hal yang menunjukan bahwa kekerasan berpacaran terjadi di semua aspek. Beberapa sumber mengatakan banyak faktor yang mempengaruhi, kenapa banyak siswa mengalami bentuk kekerasan dalam pacaran antara lain: faktor individual, sejarah kekerasan dalam keluarga, penerimaan teman sebaya, harapan peran gender, penggunaan obat-obatan, gangguan kepribadian, faktor dalam hubungan, dan faktor komunitas. Faktor individual yang dapat menyebabkan seseorang melakukan kekerasan terhadap pasangannya adalah usia muda, berada pada level ekonomi yang rendah, memiliki prestasi akademis yang rendah, serta seseorang yang sering mengobservasi ibunya yang mengalami kekerasan dalam rumah tangga, mengalami emotionally dependent, insecure dan rendahnya self esteem. Semakin banyaknya konflik yang terjadi dalam hubungan tersebut akan meningkatkan terjadinya dating violence.

Berdasarkan hasil analisis deskritif data diperoleh sepuluh butir item bentuk kekerasan dalam pacaran yang mempunyai frekuensi tinggi. Butir-butir ini terdapat dalam aspek kekerasan secara verbal dan emosional.

Menjelek-jelekkan tubuh saya (memberi julukan negatif, misal “Gembrot, Cungkring).

Untuk item pertama menjelek-jelekan tubuh saya, dari hasil penelitian dalam kekerasan dalam pacaran memiliki frekuensi kekerasan untuk 1-3 kali sebanyak 47 subjek yang mengalami. Dari hasil penelitian, masih banyak para siswa yang mengalami kekerasan. Mengapa bisa terjadi kepada remaja. Kebanyakan orang beranggapan bahwa memberika julukan kepada orang lain itu hal yang biasa, dengan sesuka hati kita memberikan nama-nama yang bukan semestinya. Bagi pasangan memberikan julukan adalah tanda sayang atau kasih, tapi kita harus mengetahui batasnya. Jika kita sudah tidak Nyaman, maka kata-kata itu sudah menjadi kekerasan, karena membuat kita tidak nyaman tersebut.

Mereka tidak mengerti, kenapa mudah terjadi tindakan kekerasan. Tindakan kekerasan tidak ada tindakan tegas. Apakah karena kekerasan ini paling mudah dilakukan dan tanpa ada payung hukumnya. Kekerasan tidak dilaporkan biasanya karena korban merasa takut akibat ancaman oleh pacar, atau iba karena pelaku memohon maaf sedemikian rupa, setelah melakukan kekerasan, sehingga korban percaya bahwa pelaku benar-benar menyesali perbuatannya dan tidak akan mengulanginya lagi.

\section{Mengatakan saya "malas".}

Untuk item kedua, Mengatakan saya "malas" Untuk 1-3 kali sebanyak 54 subjek, 4-7 kali sebanyak 20 subjek, 24 subjek untuk 7-9 kali dan 19 subjek untuk lebih dari 10 kali. Kekerasan ini terjadi bila saat bersama pelaku, korban merasa senang karena bersama dengan orang yang mereka sayang. Namun rasa senang itu hanya muncul saat tidak terjadi pertengkaran.

Sama dengan item no 1, Kebanyakan orang beranggapan bahwa mengatakan hal yang negatif kepada orang lain itu hal yang biasa, dengan sesuka hati kita mengatakan hal yang negatif tanpa kita sadari. Bagi pasangan memberikan julukan-julukan adalah tanda sayang atau kasih, tapi kita harus mengetahui batasnya. Jika kita sudah tidak nyaman, maka kata-kata itu sudah menjadi kekerasan, karena membuat kita tidak nyaman tersebut.

Kejadian ini tidak bisa terjerat hukum, tapi secara psikologis bisa menganggu korban. Korban akan memaafkan karena pelaku memohon maaf sedemikian rupa sehingga korban iba, setelah melakukan kekerasan, sehingga korban percaya bahwa pelaku benar-benar menyesali perbuatannya dan tidak akan mengulanginya. 
Mencemberuti saya dengan wajah kesal.

Untuk item ketiga, Mencemberuti saya dengan wajah kesal. Untuk 1-3 kali sebanyak 56 subjek, 4-7 kali sebanyak 26 subjek, 15 subjek untuk 7-9 kali dan 29 subjek untuk lebih dari 10 kali. Kita bisa lihat banayk subyek yang mengalami 1-3 kali kekerasan dalam pacaran.

Kebanyakan orang, melakukan hal ini untuk menyelesaikan konflik. Kebanyakan remaja beranggapan bahwa hal diatas digunakan sebagai cara untuk menyelesaikan konflik yang terjadi dalam berpacaran. Jika keinginan pasangan tidak dituruti, maka item di atas dilakukan agar korban mau melakukannya.

Kasus ini juga susah di laporkan atau ditindak secara hukum. Korban tidak melaporkan kekerasan ini, karena korban merasa iba karena pelaku memohon maaf sedemikian rupa, setelah melakukan kekerasan, sehingga korban percaya bahwa pelaku benar-benar menyesali perbuatannya dan tidak akan mengulanginya lagi.

\section{Melarang saya melakukan sesuatu dengan lawan jenis.}

Untuk item keempat, Melarang saya melakukan sesuatu dengan lawan jenis. Untuk 1-3 kali sebanyak 43 subjek, 4-7 kali sebanyak 18 subjek, 10 subjek untuk 7-9 kali dan 44 subjek untuk lebih dari 10 kali. Kasus kekerasan yang terjadi banyak dialami subyek sebanyak 10 kali atau lebih.

Kebanyakan orang beranggapan bahwa melarang pasangan melakukan kegiatan dengan orang lain, itu hal yang biasa. Pasangan dengan sesuka hati melarang tanpa meyadari akibatnya. Bagi pasangan melarang adalah tanda sayang atau kasih, cemburu, tidak ingin kehilangan pasangannya, tapi kita harus mengetahui batasnya. Jika kita sudah tidak nyaman, maka tindakan itu sudah menjadi kekerasan, karena membuat kita tidak nyaman tersebut.

Kekerasan ini terjadi karena pacar yang pencemburu atau karena ingin mejaga pacaranya. Kekerasan ini tidak dilaporkan karena korban iba karena pelaku memohon maaf sedemikian rupa, setelah melakukan kekerasan, sehingga korban percaya bahwa pelaku benar-benar menyesali perbuatannya dan tidak akan mengulanginya lagi dan tidak ada payung hukumnya. Korban merasa apa yang dilakukan pelaku tersebut, karena sayang dan menjaga.

\section{Mengawasi pergaulan saya dengan orang lain.}

Untuk item ini, Mengawasi pergaulan saya dengan orang lain untuk 1-3 kali sebanyak 60 subjek, 4-7 kali sebanyak 18 subjek, 11 subjek untuk 7-9 kali dan 28 subjek untuk lebih dari 10 kali. Bila kita lihat kasus kekerasan ini, banyak dialami 1-3 kali. Mengawasi suatu hal yang biasa bagi kita. Tapi, bila kegiatan ini terjadi terus menerus akan menjadi gangguan bagi kita.

Kebanyakan orang beranggapan bahwa mengawasi pasangan melakukan kegiatan dengan orang lain, itu hal yang biasa. Pasangan dengan sesuka hati mengawasi tanpa disadari dan mereka tidak menyadari akibatnya. Bagi pasangan mengawasi adalah tanda sayang atau kasih, cemburu, tidak ingin kehilangan pasangannya, tapi kita harus mengetahui batasnya. Bila kejadian ini terjadi terus menerus, pasangan akan semakin risih dan banyak teman yang menjahui karena tidak nyaman dengan sikap pasangannya. Jika kita sudah tidak nyaman, maka tindakan itu sudah menjadi kekerasan, karena membuat kita tidak nyaman tersebut.

Kasus kekerasan ini yang tidak akan dilaporkan, biasanya karena korban merasa takut akibat ancaman oleh pacar, iba karena pelaku memohon maaf sedemikian rupa, setelah melakukan kekerasan, sehingga korban percaya bahwa pelaku benar-benar menyesali perbuatannya dan tidak akan mengulanginya lagi, bahkan akan ditingagalkan atau diputuskan bila korban tidak memberitahu di mana berada, bersama siapa. 
Memeriksa Inbox saya dengan penuh curiga.

Untuk item keenam, Membaca isi inbox saya dengan penuh curiga. Untuk 1-3 kali sebanyak 51 subjek, 4-7 kali sebanyak 18 subjek, 13 subjek untuk 7-9 kali dan 32 subjek untuk lebih dari 10 kali. Kebanyakan orang beranggapan bahwa membaca isi inbox itu hal yang biasa, dengan sesuka hati kita membaca inbox pasangan kita. Bagi pasangan memberikan julukan adalah tanda sayang atau kasih, curiga, tidak ingin kehilangan. Pasangan tidak mengetahui batasnya. Jika kita sudah tidak nyaman, maka tindakan itu sudah menjadi kekerasan, karena membuat kita tidak nyaman tersebut.

Kebanyakan Kasus kekerasan dilaporkan biasanya karena korban merasa iba karena pelaku memohon maaf sedemikian rupa, setelah melakukan kekerasan, sehingga korban percaya bahwa pelaku benar-benar menyesali perbuatannya dan tidak akan mengulanginya. Korban takut kejadian kekerasan itu akan terjadi lagi saat mereka sedang bersama. Namun korban mencoba mempertahankan hubungan dengan pelaku karena korban berharap suatu saat nanti pelaku akan berubah, hal ini terjadi pada kekerasan yang lain juga.

\section{Mempertontonkan rasa cemburu yang berlebihan.}

Untuk item ketujuh, Mempertontonkan rasa cemburu yang berlebihan. untuk 1-3 kali sebanyak 62 subjek, 4-7 kali sebanyak 12 subjek, 13 subjek untuk 7-9 kali dan 19 subjek untuk lebih dari 10 kali kasus kekerasan yang terjadi untuk kasus ini bnayak terjadi 1-3 kali.

Kebanyakan orang beranggapan bahwa mempertontonkan rasa cemburu yang berlebihan kepada pasangan itu hal yang biasa, dengan sesuka hati kita selalu cemburu. Bagi pasangan cemburu adalah tanda sayang atau kasih, banyak berangagapan cemburu itu tanda sayang. Tapi kita harus mengetahui batasnya. Jika kita sudah tidak nyaman, maka tindakan itu sudah menjadi kekerasan, karena membuat kita tidak nyaman tersebut.

Kasus tidak dapat dilaporkan karena tidak ada hukuman pidana. Korban takut kejadian kekerasan itu akan terjadi lagi saat mereka sedang bersama. Namun Korban mencoba mempertahankan hubungan d engan pelaku karena korban berharap suatu saat nanti pelaku akan berubah, sehingga korban percaya bahwa pelaku benar-benar menyesali perbuatannya dan tidak akan mengulangi perbuatan ini lagi.

Menyatakan pada saya, seakan-akan saya sudah jadi miliknya.

Untuk item kedelapan, Mengatakan saya "malas" untuk 1-3 kali sebanyak 60 subjek. Kekerasan banyak terjadi di frekuensi 1-3 kali.

Kebanyakan orang beranggapan bahwa menyatakan seakan-akan pasangan adalah miliknya, hal yang biasa. Pasangan dengan sesuka hati melakukan tindakan ini. Bagi pasangan tindakan adalah tanda sayang atau kasih, tidak ingin kehilangan, banyak juga yang tidak mengerti apa status yang dimiliki sekarang ini. Tapi kita harus mengetahui batasnya. Jika kita sudah tidak nyaman, maka tindakan itu sudah menjadi kekerasan, karena membuat kita tidak nyaman tersebut.

Sama dengan kasus yang lain, Kasus kekerasan ini tidak bisa terjerat hukum. Tapi, bila kekerasan masuk ke area kekerasan yang membuat memar, atau secara fisik kekerasan bisa dijerat hukum. Banyak korban yang tidak melaporkan tindakan ini, karena korban merasa takut akibat ancaman oleh pacar, atau iba karena pelaku memohon maaf sedemikian rupa, setelah melakukan kekerasan. Korban mencoba mempertahankan hubungan dengan pelaku karena korban berharap suatu saat nanti pelaku akan berubah, atau karena korban terlalu sayang terhadap pelaku.

\section{Melarang saya berbaur dengan lawan jenis.}

Untuk item kesembilan, Melarang saya berbaur dengan lawan jenis sebanyak 44 subjek untuk lebih dari 10 kali. 
Kebanyakan orang beranggapan bahwa melarang berbaur dengan lawan jenis itu hal yang biasa, dengan sesuka hati kita melarang. Bagi pasangan melarang adalah tanda sayang atau kasih, menjaga kekasihnya agar terhindar dari bahaya, tapi kita harus mengetahui batasnya. Bila kejadian ini terjadi, pasangan akan risih, tidak nayaman dengan tindakan ini. Jika kita sudah tidak nyaman, maka kata-kata itu sudah menjadi kekerasan, karena membuat kita tidak nyaman tersebut.

Kasus kekerasan merupakan tindakan pengasingan, mengisolasi segala bentuk hubungan dengan pertemanan termasuk dengan lawan jenis. Kasus ini tidak dilaporkan ke ranah hukum, karena tidak berbau kriminal. Biasanya korban merasa takut akibat ancaman oleh pacar, atau iba karena pelaku memohon maaf sedemikian rupa, setelah melakukan kekerasan, sehingga korban percaya bahwa pelaku benar-benar menyesali perbuatan dan tidak akan mengulanginya lagi atau karena korban terlalu sayang kepada kekasih atau pelaku.

Menyakiti saya dengan mengungkit-ungkit masa lalu.

Untuk item kesepuluh, Menyakiti saya dengan mengungkit-ungkit masa lalu untuk 1-3 kali sebanyak 61 subjek.

Kebanyakan orang beranggapan bahwa mengungkit masa lalu adalah hal yang biasa ketika pacaran. Kekasih dengan sesuka hati kita mengungkit masa lalu tanpa memperdulikan pasangannya. Bagi pasangan mengungkit masa lalu adalah tanda kesal,cemburu, atau karena keinginan tidak dituruti. Tapi, kita harus mengetahui batasnya. Jika kita sudah tidak nyaman, maka tindakan itu sudah menjadi kekerasan, karena membuat kita tidak nyaman tersebut.

Korban mempertahankan hubungan dengan pelaku karena korban berharap suatu saat nanti pelaku akan berubah. Kasus kekerasan yang tidak dilaporkan biasanya karena korban merasa takut akibat ancaman oleh pacar, atau iba karena pelaku memohon maaf sedemikian rupa, setelah melakukan kekerasan, sehingga korban percaya bahwa pelaku benar-benar menyesali perbuatannya dan tidak akan mengulanginya lagi.

Berdasarkan pemaparan di atas, dapat kita lihat bahwa kebayakan subjek pernah mengalami kekerasan 1-3 kali sewaktu pacaran. Subjek kebanyakan mengalami kekerasan secara verbal dan emosional, seperti caci maki, curiga dll. Kekerasan verbal dan emosional sering terjadi pada korban saat korban dan pelaku bertengkar. Pelaku kurang dapat mengontrol emosi sehingga sering mengeluarkan kata-kata kasar yang tidak disadari terhadap korban dan tidak jarang pelaku melakukan kekerasan secara emosional. Misalnya dengan mengatakan hal-hal yang membuat korban sakit hati, dengan mengungkit-ungkit masa lalu, dll. Semua item bentuk-bentuk kekerasan dalam pacaran terisi semua, ini menunjukkan bahwa kekerasan berpacaran terjadi dikalagan siswa. Setiap item mempunyai frekuensi kekerasan yang berbeda-beda.

Fenomena yang nampak hanya kasus-kasus yang tanpa sengaja dan tidak diketahui, dapat dikatakan bahwa yang tampak berupa fenomena gunung es (iceberg), dimana kasus sebenarnya masih jauh lebih besar lagi, namun banyak hal yang membuatnya tidak muncul ke permukaan. Salah satunya adalah karena tidak dilaporkan.

Ada beberapa kemungkinan faktor yang dapat mempengaruhi Kekerasan dalam pacaran (dating violence) pada mahasiswa di Kabupaten Pringsewu. Menurut Siagian (2012) Kemungkinan faktor-faktor yang mempengaruhi kekerasan dalam pacaran (dating violence) tersebut antara lain adalah:

\section{Harapan Peran Gender}

Melihat hasil penelitian ini, banyak remaja perempuan yang sering mendapatkan kekerasan dalam pacaran. Kebanyakan dari subyek adalah perempuan, yag dimana perempuan itu di pandang pasif. Untuk pria diharapkan untuk lebih mendominasi sedangkan wanita diharapkan untuk lebih pasif. Pria 
yang menganut peran gender yang mendominasi akan lebih cenderung mengesahkan perbuatan dating violence kepada pasangannya, sedangkan wanita yang menganut peran gender yang pasif, akan lebih menerima dating violence dari pasangannya.

\section{Pengalaman yang Sedikit}

Pacaran merupakan hubungan yang selalu indah. Kebanyakan dari subyek adalah remaja yang belum terlalu mengenal arti dari pacaran. secara umum, remaja memiliki sedikit pengalaman dalam berpacaran dan menjalin hubungan dibandingkan dengan orang dewasa. Remaja tidak mengerti seperti apa pacaran yang benar, apakah setiap hal yang mereka lakukan saat pacaran adalah baik. Contohnya: cemburu dan posesif dari abuser dilihat sebagai tanda cinta dan sesuatu yang dipersembahkan dari abuser. Karena kurangnya pengalaman, mereka menjadi kurang objektif dalam menilai hubungan mereka.

\section{Faktor Individual}

Setiap Pribadi mempunyai pengalaman yang berbeda-beda. Remaja juga mempunyai pengalaman dan persepsi yangg berbeda. Banyak yang melakukan kekerasan karena di anggap yang dilakukan itu adalah arsa sayang. Keadaan setiap individu membuat sesorang memahami arti kekerasan berbedabeda.

Faktor demografi yang dapat menyebabkan seseorang melakukan kekerasan kepada pasangannya adalah usia yang muda dan memiliki status ekonomi yang rendah. The Health and Development Study in Dunedin, New Zealand - Dalam satu penelitian longitudinalnya menunjukkan bahwa seseorang yang berasal dari keluarga yang melakukan kekerasan- berasal dari keluarga yang umumnya berada pada level ekonomi yang rendah, memiliki prestasi akademis yang rendah atau pendidikan yang rendah, maka mereka akan melakukan dating violence.

Kekerasan bisa terjadi tanpa kita sadari di kehidupan ini. Siswa tidak menyadari kekerasan dalam pacaran karena indahnya pacaran itu sendiri. Siswa saat ini dalam masa remaja, masa peralihan dari anak-anak menuju dewasa yang mencakup kematangan mental, emosional, sosial dan fisik. Mereka mempunyai salah satu masa yang menarik yaitu trend berpacaran.

Dampak kekerasan dalam berpacaran, meliputi dampak fisik dan dampak psikis. Dampak secara fisik bagi korban kekerasan berupa rasa sakit, seperti perih, panas, memar. Dampak psikis bagi korban saat kekerasan terjadi berupa merasa sakit hati, kesal, sebel, marah, benci, tidak ingin bertemu dengan pelaku, ingin putus, sedih, menyesal. Dampak setelah kekerasan terjadi meliputi dampak fisik berupa rasa sakit, seperti rasa perih, panas, bengkak, memar pada bagian tubuh yang mengalami kekerasan. Dampak psikis bagi korban setelah mengalami kekerasan meliputi dampak positif bagi korban, yaitu korban memandang seseorang tidak hanya dari fisiknya saja, tetapi juga kepribadiannya dan korban lebih mampu mengontrol sifat tempramen yang dimiliki, dan dampak negatif bagi korban yaitu takut dengan laki-laki atau perempuan, menutup diri, menutup diri dari dunia luar, stress, nilai menurun, malas beraktifitas, sakit hati, krisis kepercayaan terhadap orang lain, trauma, marah.

\section{Kesimpulan dan Saran}

Beberapa kesimpulan berdasarkan hasil penelitian dan pembahasan hasil penelitian adalah: Bentukbentuk kekerasan yang dialami siswa ialah jarang 96, $55 \%$, kerap kali 3,45 \% dan sering sebanyak $0 \%$. Terdapat sepuluh item yang mempunyai frekuensi tinggi dan butir bentuk- bentuk kekerasan dalam pacaran yang termasuk kategori rendah tetapi memiliki frekuensi yang cukup tinggi, sebagai berikut: 


\begin{tabular}{cl}
\hline No & \multicolumn{1}{c}{ Rumusan } \\
\hline 1 & Menjelek-jelekkan tubuh saya (memberi julukan negatif, misal "Gembrot, cungkring) \\
\hline 2 & Mengatakan saya "malas" \\
\hline 3 & Mencemberuti saya dengan wajah kesal. \\
\hline 4 & Melarang saya melakukan sesuatu dengan lawan jenis \\
\hline 5 & Mengawasi pergaulan saya dengan orang lain. \\
\hline 7 & Membaca isi inbox saya dengan penuh curiga \\
\hline 8 & Menpertontonkan rasa cemburu yang berlebihan \\
\hline 9 & Melarang saya berbaur dengan lawan jenis \\
\hline 10 & Menyakiti saya dengan mengungkit-ungkit masa lalu
\end{tabular}

Berikut ini dikemukakan beberapa saran yang sesuai dengan hasil penelitian untuk berbagai pihak. Dosen pembimbing diharapkan peka terhadap kebutuhan para mahasiswa yang selama ini belum tercapai dalam hal berhubungan dengan lawan jenis. Dosen pembimbing mampu memberikan layanan bimbingan dan konseling pribadi sosial yang efektif bagi para mahasiswa sehingga semakin mengerti dan memahami kekerasan dalam pacaran.

Siswa semakin sadar dan mengerti akan kekerasan dalam pacaran. Siswa semakin sadar untuk berefleksi sampai sejauh mana mereka mengerti akan arti pacaran dan kekerasan dalam pacaran. Siswa mampu mengatur diri terutama dalam kegiatan berhubungan dengan lawan jenis, sehingga siswa dapat mengantisipasinya.

Setelah mendapat masukan yang terkait dengan penelitian kekerasan dalam pacaran mampu mengembangan penelitian lain yang terkait dengan kekerasan dalam pacaran, yaitu lebih memperkaya teori-teori terbaru yang berkaitan dengan kekerasan dalam pacaran. Menggunakan skala populasi dan responden yang lebih besar agar dapat lebih menggambarkan kekerasan dalam pacaran. Mampu menilik dari sisi pelaku kekerasan dalam pacaran, agar semakin melengkapi penelitian sebelumnya.

Penelitian selanjutnya juga melihat dari sisi faktor-faktor korban dan pelaku, bisa juga mengunakan penelitian kuantitatif kulitatif.

\section{Daftar Pustaka}

Adetunji Adeleke. (2009). National Assembly. Nigeria.

Adimassana, YB. 2001. Reader Teologi Moral. Yogyakarta: Universitas Sanata Dharma

Ahmadi, A. 2004. Psikologi Belajar. Jakarta: Rineka Cipta

Arya. 2010. Kekerasan Dalam Pacaran. Artikel. http:/belajarpsikologi.com. Diakses tanggal 10 Juli 2012.

Azwar, Saifuddin. 2008.Penyusunan Skala Psikologis. Yogyakarta: Pustaka Pelajar

Azwar, Saifuddin. 2012. Reliabilitas dan Validitas. Yogyakarta: Pustaka Pelajar

Basyarudin, A. 2010. Pacaran di Kalangan Remaja. Artikel. http://dc378.4shared.com. Diakses tanggal 20 Januari 2013 pukul 13.32.

Dinastuti. 2008. Gambaran Emotional Abuse dalam Hubungan Berpacaran pada Empat Orang Dewasa Muda. Jurnal 
Manasa, Volume 2, Nomor 1.

Darajat, Zakiah. 1990. Kesehatan Mental. Jakarta: Gunung Agung

Fucchan, Arief. H. 2007. Pengantar Penelitian Dalam Pendidikan. Yogyakarta: Pustaka Pelajar.

Furlong, Michael, et al, 2005. Dating violence patterns of California adolesce, wwww.proquest.com, diakses 14 November 2012 pukul 17.56

Gunarsa, S.D \& Gunarsa, Y.S.D. 2002. Psikologi Untuk Muda-Mudi. Jakarta: BPK Gunung Mulia.

Hadi. 2010. Pengertian Pacaran. Artikel. http://muda.kompasiana.com. Diakses tanggal 10 Juni 2012.

Hurlock, E B. 1992. Psikologi Perkembangan (Suatu Pengantar Sepanjang Bentang Kehidupan). (terjemahan: Istiwidiyanti). Edisi V. Jakarta: P.T. Gelora Aksara Pratama.

Hurlock, Elizabeth B. Alih bahasa Isti Widayanti dan Sudjarwo. (1999). Psikologi Perkembangan. Jakarta: Erlangga.

Baron, Byrne \& Branscombe.2006. Social psychology (12th ed.). Boston. USA

Jombang women's crisis center. 2013. Kekerasan dalam Pacaran. wwww.wccjombang.or.id. Diakses tanggal 11/11/2012 pukul 16.45.

Kamus Besar Bahasa Indonesia. 2002. Jakarta: Depdiknas

Kellen.2002. The Facts on Teens and Dating Violence. wwww.proquest.com, diakses 28 November 2012 pukul 13.06

LBH Apik, 2011. Laporan Tahun 2011 LBH Apik Jakarta “Jerat Birokrasi, Patriarki Dan Formalisme Hukum Bagi Perempuan Pencari Keadilan". Artikel. http://wwww.lbh-apik.or.id. Diakses tanggal 10 Juni 2012 pukul 16.51.

Murray, Jill. 2009. But i love him. Jakarta: Bhuana Ilmu Populer.

Nurihsan, A.J. \& Sudianto, A. 2004. Manajemen Bimbingan E Konseling di SMA Kurikulum 2004. Jakarta: Gramedia Widiasarana Indonesia.

O'Kefee. 2005. Teen Dating Violence: A Review of Risk Factors and Prevention Efforts. National Resource Center on Domestic Violence. USA

Pepermin. 2006. The National Clearinghouse on Family Violence and Dating Violence. USA

Priyani R. 2010. Menjadi Pria-Wanita Dewasa (Week-End Moral). Yogyakarta: Universitas Sanata Dharma

Riani. (2012). Kekerasan dalam pacaran dan bagaimana bersikap. Kesehatan.kompasiana.com/kejiwaan/2012/06/26/

Rice, F. Philip. 2005. The adolescent development, relationship, adn culture., 9 edition, Allyn ad Bacon, USA.

Roudsari BS, Leahy MM, Walters ST. 2009. Correlates of dating violence among male and female heavy-drinking college students. J Interpers Violence. 2009 Nov;24(11):1892-905.

Rossiningtyas, W.2006. Perilaku Remaja yang Teribat dalam Dating Violence ditinjau dari Social Learning Theory. Tesis (tidak diterbitkan). Depok: Fakultas Psikologi Universitas Indonesia.

Santrock, John W. 2003. Adolescence: perkembangan remaja. Jakarta: Erlangga

Satria. 2011. Pengertian Pacaran. Artikel. http://id.shvoong.com. Diakses tanggal 18 November 2012 jam 16.30.

Santrock, John W. 2007. Remaja Ed. 11 Jilid 1. Jakarta: Erlangga.

Santoso, T. 2002. Teori-Teori Kekerasan. Jakarta: Ghalia Indonesia. Sarwono, Sarlito. 2005. Psikologi Remaja. Jakarta: Raja Grafindo Persada.

SeBAYAPKBI Jatim. 2007. Kekerasan dalam pacaran. wwww.kiatsehat.com. Diakses tanggal 17092012 pukul 13.00.

Sri Rumini \& Siti Sundari. 2004. Perkembangan Anak \& Remaja. Jakarta: Rineka Cipta

Surachman, Winarno.1986. Pengantar Interaksi Belajar Mengajar. Bandung: Tarsito. 
Sony Set.2009. Teen Dating Violence- Stop Kekerasan Dalam Berpacaran. Yogyakarta: Kanisius.

.2008. “JBK-Stop Dating Violence!". http://stopdatingviolence.blogspot.com/Diakses tgl 28/05/2012 pukul 13.26

Sugiyono. 2011. Statistika untuk Penelitian. Bandung: Alfabeta.

Subhan, Z. 2004. Kekerasan Terhadap Perempuan. Yogyakarta: Pustaka Pesantren.

Sukardi, K.D. 2010. Proses Bimbingan dan Konseling di Sekolah. Jakarta: Rineka Cipta

Siagian, Olivia. (2009). Gambaran Bentuk-Bentuk Dating Violence Pada Remaja yang Berpacaran di Kota Medan. Skripsi (tidak diterbitkan). Medan: Falkutas Psikologi. Universitas Sumatera Utara.

Sofyan S. Willis. (2005). Remaja dan Masalahnya Mengupas Berbagai bentuk Kenakalan Remaja seperti Narkoba, Freesex dan Pemecahannya. Bandung: Alfabeta.

Tribun Jogja. 2012. 14 Meninggal Karena kekersan dalam pacaran. wwww.tibunjogja.com. Di akses pada 06/07/2012 pukul 11.30 .

Yusuf Syamsuf. 2010. Psikologi Anak dan Remaja. Bandung: Remaja Rosdakarya.

Warsana, W. 1992. Kekuasaan dan Kekerasan Menurut John Galtung. Yogyakarta: Kanisius.

Winkel, W.S, Hastuti, S. 2004. Bimbingan dan Konseling di Institusi Pendidikan. Yogyakarta: Media Abadi.

WHO. 1999. World report on violence and health. Switzerland.

Zulkifli, L. 2003. Psikologi Perkembangan. Bandung: Remaja Rosdakarya. 